\section{Just doing it: enjoying commodity fetishism with Lacan}

Organization

@SAGE

\title{
Steffen Böhm
}

Essex Business School, University of Essex

\section{Aanka Batta}

Essex Business School, University of Essex

\begin{abstract}
Despite prolonged resistance campaigns against what are regarded as unethical production practices of companies such as Nike, people around the world still seem to be happy to spend a lot of money buying expensive consumer products. Why is this so? In this article we discuss this question through the lens of the concept of fetishism. By discussing texts by Freud and Marx, amongst others, we first explore the genealogy of the concept of fetishism. We then develop a Lacanian reading to understand how processes of fetishization dominate today's capitalist society, producing a modern subject that constantly desires to consume more in order to constitute itself. We argue - with Lacan - that at the heart of this process of the constitution of the subject through consumption is enjoyment or, what Lacan calls, jouissance. Capitalism-as any other socioeconomic regime — can thus be understood as a system of enjoyment.
\end{abstract}

\section{Keywords}

consumer capitalism, enjoyment, Lacan, Freud, Marx, Nike, subjectivity, sweatshops

It's surplus jouissance, but it's not nameable, even if it's approximately nameable, translatable, in this way. This is why it has been translated by the term 'surplus value'. (Lacan, 2007: 147)

Since the mid-1990s the multinational shoes and sports clothing company Nike has been in the 'bad books' of ethically concerned commentators, anti-capitalist movements and other protesters and academics alike (e.g. Klein, 2000). Nike has been charged with exploitative production practices in 'third world' sweatshops, paying workers very little money and generally providing poor working conditions, while charging extortionate prices for their fashionable trainers in their own NikeTown 
branding temples and the thousands of other shopping outlets where the company's products are on sale. 'If a pair of Nike Air Jordans (are) retailed for $\$ 130$ ', it is asked, 'but cost a fraction of that to make, aren't they overpriced? Where does the rest of the money go?' (Bullert, 1999: 5).

For some political economists (e.g. Callinicos, 2003) the answer to these questions is obvious, as they point to the fundamental problems of the capitalist system since its inception. Nevertheless, NGOs, charities and social movements, such as No Sweat, Sweatshop Watch, War on Want, amongst others, have put increasing focus on such questions particularly since the mid-1990s. Such campaigns alongside other more traditional labour unions are an attempt to expose the poor working and pay conditions that many sweatshop workers face in the so-called 'developing world'. There has been a wide range of literature and media engaging critically in the sweatshop debate: NGO and charity reports (Foo and Fortunato Bas, 2003; War on Want, 2005, 2006), films such as China Blue, academic articles (Knight and Greenberg, 2002; Rodríguez-Garavito, 2005; Soldatenko, 1999), as well as books aimed at the more general reader (Danaher and Mark, 2003; Klein, 2000; Louie, 2001). In organization and critical management studies, it is primarily thanks to Boje's work (e.g. 2001) that the malpractices of Nike and other multinationals is fairly widely discussed and taught.

This article, however, is not about analysing the successes and failures of the anti-sweatshop resistance campaign (see Boje, 2001; Robbins, 2002; Spencer and Praparpun, 2002). Instead, our starting point is the fact that, despite the well-documented shortcomings of the corporate practices of Nike and other multinational consumer product companies, and despite the resulting heightened consumer awareness of politico-economic issues, millions of consumers still flock to NikeTown and other shopping temples to buy expensive branded products. In this article we explore this apparent success of capitalist consumption through the concept of 'fetishism', which, it has been argued, can be a useful theoretical category for understanding contemporary capitalist society and subjectivity (Böhm, 2005, 2006a). In fact, the concept has been so widely used in cultural and social theory that one can talk about 'a certain fetishization of fetishism' (Miklitsch, 1998: 25). Nevertheless, the term has hardly had any exposure in critical organization and management studies (although there are some exceptions: Brewis and Linstead, 2000; Knights and Willmott, 1989; Marsden, 1999; Thompson, 1983). This can perhaps be partly explained by the popularity of labour process theory, which has focused its energy on critiques of the control and production of labour in the workplace, as well as the more recent popularity of Foucauldian studies of work identities (Böhm, 2006a; Spicer and Böhm, 2007). What both of these approaches miss is an engagement with the realms of cultural consumption. It is precisely this dimension, in our view, which helps us understand why people keep on buying Nike trainers despite the manifold resistances and critiques articulated against the company.

In order to understand the workings of today's consumer capitalism, we will discuss the concept of 'commodity fetishism', which was first conceptualized by Marx (1976) in his 19th century classic, Capital. In the early parts of the 20th century critical theorists, such as Adorno (2005), Benjamin (1999) and Marcuse (1987) argued that Marx's economic analyses need to be complemented by, and integrated into, a wider theory of capitalist subjectivity (Buck-Morss, 1989). Hence, many of its representatives turned to psychoanalysis, and Freud in particular, aiming to understand how capitalist socio-economic relations constituted, changed and, in their words, 'damaged' modern subjectivity (Adorno, 2005). For such a project 'the concept of "commodity fetishism" offers an especially fertile discursive constellation in which to explore the relation between Marxism and psychoanalysis, where the conceptual switch-point between the two discourses is, of course, fetishism' (Miklitsch, 1998: 25). According to Miklitsch, the aim of such an 
intellectual project is 'to be more, not less dialectical' (Miklitsch, 1998: 27, emphasis in original). For critical theorists, the concept of commodity fetishism thus provided the opportunity to broaden Marx's classical categories. Their aim was to understand how people take an active part - through processes of desire, pleasure and consumption - in the constitution and reproduction of capitalist social relations.

After World War II this intellectual project of bringing Marx and Freud together and exploring the subtleties of the pleasures of consumption was then extended by a whole host of French writers (e.g. Althusser and Balibar, 1970; Baudrillard, 2001; Debord, 1994; Lyotard, 2004). Baudrillard (2001) took a particular interest in the concept of 'commodity fetishism'. He embedded it in a semiological framework, understanding the commodity as part of a general system of signs and meanings. If Marx's key aim was to understand the realms of economic production, Baudrillard argued, then there is also a need to explore in much more detail how the system of signs and symbols of consumption works. This is precisely the point at which Jacques Lacan enters the scene. As far as we are aware, he never talked directly about 'commodity fetishism'. Lacan, however, was very much aware of Marx's oeuvre and the wider Marxist tradition. In fact, he frequently made direct and indirect reference to the work of Marx, particularly in his Seminars XVI and XVII (Lacan, 2006, 2007). However, his groundwork is laid in Freudian psychoanalysis, and he was greatly informed by the linguist de Saussure (1995) from whom Lacan borrows the understanding of language as a structure in order to conceptualize human subjectivity. It is precisely Lacan's theory of the subject, structured by linguistic categories, that has influenced a range of writers in social and cultural theory, including those interested in merging Marxian and psychoanalytic understandings of fetishism to conceptualize capitalist subjectivity (e.g. Miklitsch, 1998; Stavrakakis, 2007; Stratton, 2000; Žižek, 1997). What these writers have often found particularly of interest in Lacan are his conceptions of the 'Real' and 'jouissance', which will also play a key role in this article. Lacan's realm of the Real and jouissance is the set of libidinal drives that cannot be symbolized. They describe the realm beyond socially sanctioned enjoyment, or rather, pleasure (Lacan 1998: 184). Hence, these terms point to those libidinal mechanisms that are non-symbolizable and therefore never fully attainable or even understandable.

In the wider social sciences it has been long recognized that 'psychoanalytic theory is eminently qualified to capture, map and interpret these mechanisms in ways that more traditional analyses and the standard leftist critiques have been unable to envisage and/or fully develop' (Stavrakakis, 2007: 231). Yet, it has taken the field of organization and management studies some time to make use of the discourse of psychoanalysis for a critique of organizational life under contemporary capitalism. Recently, however, the importance of Lacan for the study of organization has become more recognized; we could mention here Arnaud (2002), Arnaud and Vanheule (2007), Böhm (2005, 2006a), Contu (2008), Driver (2009a, 2009b, 2009c), Essers et al. (2009), Harding (2007), Jones and Spicer (2005), Roberts (2005) and Vanheule et al. (2003). We would like to acknowledge the contribution made by these authors for developing a Lacanian understanding of the concept of organization. However, we will not discuss these writings in more detail, instead focusing on exploring what a Lacanian conception of commodity fetishism could look like and in what way such an analysis would be of importance for organizational theorists. The wider aim of this article is to show how a Lacanian conception of commodity fetishism can help us to understand capitalist processes of organization constructing specific subjectivities related to consumption. Before we engage in a discussion of Lacan, however, we will prepare the ground for an understanding of capitalist subjectivity by providing a short genealogy of the concept of 'fetishism'. 


\section{Fetishism: a short genealogy}

\section{Anthropology's fetish}

One of the most authoritative genealogies of 'fetishism' has been provided by Pietz whose essay trilogy 'The Problem of the Fetish' was published in the journal Res in the 1980s $(1985,1987,1988)$. Pietz traces the term to the Portuguese of the late Middle Ages, for whom feitiço 'meant "magical practice" or "witchcraft" performed, often innocently, by the simple, ignorant classes'. Pietz goes on to say that "feitiço derives from the Latin adjective facticius, which originally meant "manufactured" (1985: 5). The term then came to be used by Portuguese explorers to describe the religious practices of the West African natives who seemed to worship specific objects with magical powers. For the Portuguese explorers the 'fetish' is an object that is believed to have magical powers and thus attracts excessive and irrational investments. Brosses (1760) was one of the first anthropologists who employed 'fetishism' as a general descriptive term and he claimed that Egyptian hieroglyphics were the signs of a fetishistic religion. Thus, according to the anthropological meaning of the term, the fetishist believes the fetish to be something supernatural and, at once, an objective, natural fact. Hence in pre-capitalist societies fetishism describes the relationship between the subject and the natural world; it bridges the gap between the sacred and the profane to produce an organic unity.

Taussig (1980) maintains that this organic unity was also extended into the realm of the production of goods. For him, the economies of pre-capitalist societies were characterized by products which deeply embodied the social (fetish) milieu they were produced in. In other words, individual products, if not always, were the outcomes of fetishism or were even seen as fetishes themselves. Additionally, Gamman and Makinen argue that 'the history of the concept of fetishism has always been connected to commercial relations' (2004: 28). This is because most early European explorations were not necessarily about colonialization of foreign lands, but rather about establishing new trade routes. Hence, in order to do business with native populations, merchants in Africa were confronted and perhaps involved with peculiar rituals, which, with the help of anthropologists, they termed 'fetishism'. Hence, 'the idea of the fetish originated in a mercantile intercultural space created by the ongoing trade relations between cultures so radically different as to be mutually incomprehensible' (Pietz, 1987: 24). This mutual incomprehension resulted from a distance that could not be simply overcome by trade. Pietz suggests that this distance might have been even brought about, or at least reinforced, by trade relations. Although Pietz does not say so explicitly, his view could imply that he sees Marx's writing on commodity fetishism as an extension of this creation of distance, continuing a Western tradition of colonial belittlement and degradation of other cultures.

\section{Marx's fetish}

Marx starts his discussion of 'commodity fetishism' by talking about a 'normal' wooden table, which is 'an ordinary, sensuous thing. But as soon as it emerges as a commodity, it changes into a thing which transcends sensuousness (1976: 163). Marx uses this story of the table to show how a simple, ordinary thing is turned into something quite different, almost alien, once it enters the capitalist market. In there 'the table' transforms into a commodity, something that can be exchanged with other commodities and bought for money (which is, of course, also a commodity for Marx, albeit a special one). In Capital, Marx shows that the creation of a commodity is quite a grotesque thing to happen. This is not 'natural', as it were. This is something specific to a system of capitalist relations, which turns ordinary things, like tables, into objective, abstract entities that are exchanged within an artificially created market in order to make a profit for the owner of the table. 
This very configuration Marx sees as, what he calls, a 'reversed relationship' (1964: 7); a relationship in which, instead of man's activity being free activity, as it should be by laws of nature-is now an 'estranged relationship' between workers and non-workers (or consumers) and between workers and their products (Marx, 1964). For Marx, the relationship between the worker and the non-worker is that of exploitation and that between herself and her product is that of her own product becoming alien to herself (Marx, 1964: 6). 'The more civilized the object, the more barbarous the worker' (Marx, 1964: 4), implying that the more we put into the aesthetics of a commodity, the more of ourselves we lose. Hence, however beautiful the commodity, however fashionable or innovative, there is an estrangement between the producers of the commodity (labour) and consumers. That is, once put together as a commodity, a product - such as a Nike trainer-is outside the will, foresight and action of the individual. It is in the context of this understanding that Marx discusses 'commodity fetishism':

The mysterious character of the commodity-form consists therefore simply in the fact that the commodity reflects the social characteristics of men's own labour as objective characteristics of the products of labour themselves, as the socio-natural properties of these things. Hence it also reflects the social relation of the producers to the sum total of labour as a social relation between objects, a relation which exists apart from and outside the producers. Through this substitution, the products of labour become commodities, sensuous things which are at the same time supra-sensible or social ... I call this the fetishism which attaches itself to the products of labour as soon as they are produced as commodities, and is therefore inseparable from the production of commodities. (Marx, 1976: 165, emphasis added)

The key word in this passage is 'substitution'. What is being substituted are social relations between people with relations between objects or things. That is, the social labour that goes into producing a product, such as a table or a Nike trainer, is becoming objectified once this product enters the capitalist market to become a commodity. According to Billig's reading of Marx, 'custom, or habit, fixes a price to commodities; and in consequence, the hidden secret disappears from awareness' (Billig, 1999: 316). For example, when we enter NikeTown to buy a pair of trainers, we are not told who exactly produced this pair of shoes, nor do we get to know from which of the outsourcing factories in Asia the product originates. Marx's point is to show that this impersonal objectivity is the very point of capitalist markets, which make different things comparable to each other by assigning exchange values to them. Now, once these products enter the market, we only recognize them as commodities, or 'magical objects', that have become extra-sensuous things. This very process is what Marx calls 'commodity fetishism'.

Marx has been accused of a utopian and somewhat naïve humanism by some writers (e.g. Barrett, 1991). They argue that Marx's conception of 'commodity fetishism' points to the possibility of a future society that would be properly emancipated and be able to rid itself of the need of such a substitution process. In such a society social relations would, perhaps, be fully transparent, allowing people to relate to each other directly, that is, humanely (see Marx, 1976: 171-172). According to Pietz (1993), however, Marx's use of the concept must be seen in relation to his life-long interest in an analysis of the relationship between religion and economics. He maintains that Marx first used the term 'fetishism' in 1842, when he defined it as 'the religion of sensuous desire', pointing to the relationship between the 'sensuous desire' of individuals and historically and culturally specific situations. For Pietz, Marx was very much aware that 'like fetishist cultures, civil society achieved its unity not by finding a principle of universality but endlessly weaving itself into a "system of needs"-a libidinal economy' (1993: 140-141). Thus 'fetishism' serves Marx with the possibility of explicating his materialist-phenomenological conception of the sensuous, active and desiring 
subject. A subject which is nonetheless embedded in a particular historical juncture of specific, that is objective, divisions of labour (Pietz, 1993). It is Pietz's (1993) interpretation of Marx's conception of commodity fetishism as libidinal economy that provides the link to psychoanalysis.

\section{Freud's fetish}

Freud, nearly 40 years after Marx's death, wrote an essay called 'Fetishism', which now attaches a pathological and sexual connotation to the term. According to Freud (1927: 353), fetishism is triggered by a trauma; the trauma that the mother lacks a penis and the ensuing fear of castration that pathologically leads to the substitution of a sexual object with an Other. In fetishism 'an inanimate object or a part of the body becomes the focus of arousal in preference to a person' (Gamman and Makinen, 2004: 3). For example, in extreme sexual fetishism orgasms are achieved 'over objects such as silk, mackintoshes, cars, string, books, plaster casts and white socks' (Gamman and Makinen, 2004). The fetishistic fantasy tries to reduce the lack and the anxiety of castration creating something like a harmonious picture that enables the subject to live without fear.

There are obviously a wide range of feminist critiques of the language Freud uses in his analysis of fetishism. For Grosz (1990), for examples, the language of fetishism reinscribes patriarchal narratives of phallic domination; that is, it re-emphasizes the phallus as the male anatomy that dominates societal imagination. While this is a very worthwhile critique, we see Freud's conception of fetishist substitution as a social pathology. That is, we see fetishism as a more general reflection of the subject's narcissism; his or her own fear and anxiety of castration (Freud, 1927). As Freud points out, this anxiety is a repression that is responsible for the genesis of neurosis (Freud, 2003/1916). Being the precondition for the construction of symptoms, we understand that the fetishist's symptoms are thus a 'substitute for something that is held back by repression' (Freud, 2003/1916: 343). All symptoms serve the intention of sexual satisfaction that neurotics lack in their lives. However, according to Freud (1927), the fetishist displays the existence of both neurosis and psychosis. While the neurotic process of substitution is seen by Freud (1924) as a normal part of human development, he refers to psychosis when patients have lost touch with reality. The fetishist's ambivalent state between neurosis and psychosis is evident in the way he or she treats the object. On one hand, it is an object of desire that is worshiped while accepting reality. On the other hand, the object can be mistreated and abused as a disregard of reality. The two contradictory actions result, according to Freud, in reinitiating his or her sexual wishes instead of satisfying them. Hence, he or she can be locked in a vicious circle of narcissistic fetishism.

The Freudian notion of fetishism can simply be seen as a problem and a perversion - a pathology that needs to be cured (see Polhemus and Randall, 1994). However, in cultural and political critique Freud's fetishism has been used in a far more affirmative way. As indicated in the introduction, critical theorists, such as Marcuse (1987), Fromm (1969), Adorno (2005) and Benjamin (1999), have sought to read Freud and Marx together in their attempt to critique the historical emergence of capitalist culture and subjectivity. The Arcades Project (Benjamin, 1999), for example, explores the rise of the 19th century Parisian shopping arcade, showing how the commodity becomes a key cornerstone in the way social relations are ordered under capitalism (see also Böhm, 2006a, 2006b). What critical theorists have attempted to do is to merge Freud's psychoanalytic studies with Marx's economic analyses, as this might respond to some of the critiques advanced at both Marx and Freud. On the one hand, Freud can be read in an ahistorical manner; that is, his psychoanalysis can be seen to be only geared towards the uncovering of individual psychological traits and pathologies. What would thus be needed is a placing of human subjectivity within specific - materialist and historical— processes. On the other hand, what might be missing from Marx 
is an in-depth analysis of the psychodynamic processes of capitalist subjectivity. Critical theorists have thus tried to examine why and how people are lured into the commodity fetish. They ask: Why do people keep on shopping, even if they apparently already have everything? Although many people know of the apparent production malpractice of companies such as Nike, why do the majority keep on flocking to the shops? Why are we staying on the carousel of commodity production and consumption (Böhm, 2006b), to speak metaphorically, if we could also jump off and explore new ways of enjoyment?

As Žižek $(1989,1997)$ argues, there has often been more than a hint of humanism in the analyses of Marx and critical theorists. The emancipatory message has often been that, if only we can get rid of commodity fetishism, there will be a fully transparent society in which people do not need to transfer their anxieties and fears to any fetish object (see Marx, 1976: 171-172). In the future society no substitution will be needed, as we can enjoy reality directly, critical theorists sometimes seem to say or imply. Žižek's Lacanian reading is very critical of such a conception of emancipation. For Žižek (1989, 1997), the commodity is only one particular social fetish that, nevertheless, has dominated capitalist relations. According to him (1997: 105-106), fetishism has a constitutive character in all societies. That is, the fantasy that fetishism describes is at the heart of what we call 'the subject' as such. To explore this claim in detail, let us therefore turn to Lacan.

\section{Introducing Lacan's conception of the subject and fetishism}

In his 1955 lecture 'The Freudian Thing, or the meaning of the return to Freud in psychoanalysis' Lacan curiously talks about a 'desk' - which presumably is just the desk in the lecture hall where he is giving his talk. But we are led to believe that he actually had Marx's 'table' in mind that features so prominently in his analysis of commodity fetishism. In this lecture he says: 'For this desk, no less than the ego, is dependent on the signifier, namely on the word' (1977: 132). In our view, this is precisely where Lacan and Marx meet. While Marx talks about an extra-sensuousness that endows the commodity, Lacan talks about the symbolic order, the Other, the chain of language signifiers that attach themselves to ordinary things like tables to make them into commodities. These commodities, such as tables, have grotesque ideas 'far more wonderful than if it were to begin dancing of its own free will' (Marx, 1976: 163). In the same way Lacan sees the 'I' becoming a subject only through the structure of language, which he calls the 'symbolic'. As Sheridan, the first English translator of Écrits, Lacan's most popular book collection, explains, the symbolic does not refer to 'icons, stylized figurations, but signifiers, in the sense developed by Saussure and Jakobson, extended into a generalized definition' (1977: xi).

For Lacan, the subject - just as the table - is dependent on signifiers which make up our symbolic order including language. This allows him to conceptualize the subject in relational terms, whereby psychoanalysis is not equal to psychology (Lacan, 1977: 287). Psychoanalysis is about understanding the relation between linguistic structures and individuals that produce wider social subjectivities. And, as Sheridan rightly asks: the question is precisely whether this linguistic structure, this symbolic order, 'is or is not complete' (Sheridan, 1977: xi). For Lacan, there is a constitutive lack that describes both the subject and the Other. Hence, both can never be complete, but at the same time they are as complete as they can be. We will come back to this crucial point later on in this article, but for the moment we can say that, with Lacan, openness (lack) and completeness (subject, Other) constitute each other.

According to Lacan (1977: 103-104), the system of signifiers, or the Other, begins to determine human subjectivity during what he names the 'mirror stage', which lasts from about 6 months to about 18 months during the infant's development. During the 'mirror stage' 'the child begins to 
become engaged in the system of the concrete discourse of the environment' (Lacan, 1977). It is then, Lacan says, that the desire of the little child has already become the desire of another, of an alter ego who dominates him and whose object of desire is henceforth his own affliction' (Lacan, 1977). This is, according to Lacan, the start of the alienation of the subject, the identification with an other-the child's image in the mirror-that determines the I. At about 18 months the mirror stage comes to an end. At that time, Lacan says, the mirror image is replaced by what he calls 'socially elaborated situations'. He continues: 'It is this moment that decisively tips the whole of human knowledge into mediatization through the desire of the other' (Lacan, 1977: 5-6). The 'mirror stage' is hence the starting point for the Lacanian subject's constitution through images and discourses, or the Other.

The image is also of importance in Lacan and Granoff's (1956) article called 'Fetishism: The Symbolic, the Imaginary and the Real', which is a commentary on, and perhaps a reinterpretation of, Freud's classical essay equally called 'Fetishism'. In this essay, Lacan and Granoff (1956: 272) argue that fetishism occurs when language is transferred to an image, which stands in contrast to Freud's emphasis of the process of sexual substitution. Another way to put this is that with Lacan there is a move from the penis to the phallus. Freud's conception of 'fetishism' is about the little boy fearing he might be castrated. This fear is normally addressed by the Oedipus complex that sees the Father, and his penis, to become the central, patriarchal figure to dominate the bourgeois nuclear family. That is, with Freud desire is first and foremost sexual. His clinical account of fetishism debates how little boys are brought up to become respectable members of the Father's nuclear family, which, for Freud, is the unit that constitutes modern capitalist society. Thus, 'western capitalist society is powered by the focused and enhanced sexual desire which is formed through the individual's - in particular the male's - psychosexual development in the family' (Stratton, 2000: 6). In contrast, for Lacan, it is not the real family father and his penis that drive human development, but the Name-of-the-Father and the phallus, both of which are symbolic, mythical signifiers that mark the formation of society. Lacan writes: 'the phallus is the privileged signifier of that mark in which the role of the logos is joined with the advent of desire' $(1977: 288)$. This phallus is owned by no-one, as it is located in the realm of the symbolic, the structure of language. According to Lacan, there is desire because everyone wants to have the phallus, or what he calls the bar or column, that which stands out in society, that which has a signal function. Everybody desires this column, the Other, but nobody can ever fully get it. This structure of desire and lack applies to both men and women - another difference to Freud - as the Name-of-the-Father, the state, the policemen, the representatives of the Other, constitute their subjectivity.

A key aspect of Lacan's conception of the Other - or the Name-of-the-Father, or the fetishistic image - is that it can never be fully functioning. This is because there is something that Lacan names jouissance, which describes the lack that escapes the Other. This is the realm of what Lacan calls the Real, that which cannot be symbolized. It is the realm that constitutes the limits of the Other, as it is the limit of the subject itself. This is 'exactly what permits the emergence of desire; a desire which is structured around the unending quest for the lost/impossible jouissance. Impossible because if the subject does not have it, neither does the big Other, the socio-symbolic system. Both subjective lack and the lack in the Other are lacks of jouissance. Lost because it is posited as lost, introducing thus the idea that it can be refound' (Stavrakakis, 2000: 88, emphasis in original).

To sum up, we can say that Lacan's conceptions of the subject and fetishism are located in the realm of language and symbolic relations. Whereas, for Freud, fetishism operates as a sexual category, and Marx connects the term to the 'libidinal economy' of capitalism, Lacan sees fetishism as a more general linguistic and symbolic process of substitution. This process of the Other determining the subject starts with the infant's 'mirror stage' and, later on in life, continues with instances of 
fetishism when anxieties are transferred to social images and symbols, such as the Name-of-theFather. For Lacan, it is precisely this name, or what he calls the 'master signifier', that determines the human subject. To explore this further and connect Lacan specifically to a critique of capitalist subjectivity and categories of consumption, let us now return to a discussion of Nike.

\section{A Lacanian reading of Nike's fetish}

Nike and particularly its 'swoosh' logo are probably amongst the most recognized brands in the world, involving one of the highest advertising budgets amongst multinational companies worldwide. As Žižek (2006) notes, many commentators find it problematic that multinationals, such as Nike, are not more than big marketing and design agencies. In this way Nike is a good example of the so-called knowledge economy that sees Western knowledge workers (designers, marketers, advertisers, web and communication specialists, etc.) produce an immaterial product, the Nike brand, while the actual trainers are produced by contractors in Latin American or Asian low-cost countries. A Nike commodity chain analysis (Gereffi and Korzeniewicz, 1994) would reveal that the company publishes production tenders for various shoe ranges, and the independent contractors then fall over each other to secure the rights to produce them. These tenders are of course primarily won on price and flexibility: the cheaper a contractor can produce a trainer and ship it to Europe or North America, and the quicker it can change an order, the more likely it is selected by Nike. Most of these production contracts are short-term, so that contractors are kept on their toes and at arm's length (Domberger, 1998: 129). It is easy to see the possibilities of downward price spirals, at the far and receiving end of which are the teenagers and women workers who get a few cents for sowing a Nike football or pair of trainers.

It is within this context that the anti-sweatshop campaign has emerged. It has brought to our attention the difficult working conditions, the exploitation and dehumanization that are part and parcel of the global economy and hence has helped to politicize consumption, to put Nike and other multinationals and their production practices on the spot. One of the aims of this campaign has been to improve the working conditions and wages of the workers in low-cost countries. However, what has also been caught up in this campaign is the call by many Western critics for this production to be brought back 'home'. That is, multinationals like Nike are criticized - particularly by labour unions - for just running virtual operations in Western countries, concentrating on design and branding. In this way, it is argued, the West simply becomes an 'experience economy' (Gilmore et al., 1998) — or we could call it an 'enjoyment economy', a kind of big Disneyland — rather than developing its own 'real economy', its own industrial and manufacturing strength.

Both the 'anti-sweatshop' and 'bring-our-production-home' responses are, in our view, limited, as they seem to fall short of a critique of the workings of commodity fetishism. 'If only Nike would be more of a "real economy" company, paying its workers decent wages and pensions, then things would be better', some of the campaigners seem to be arguing. Although this kind of argument seems to be particularly attractive in today's deep economic crisis, we would maintain that some caution needs to be applied. In fact, as we are arguing in this article the workings of commodity fetishism, are proper to all capitalist production and consumption processes, and tie individual consumers and the mass social body as such to a continuous reproduction of capitalist commodity relations. Even if Nike produced its trainers say in the US, paying its workers a decent living wage, there would still be an alienation and perversion at the heart of its commodity relations making it fundamentally problematic. Equally, even if 'sweatshop' workers in the so-called 'third world' would be paid better wages, commodity fetishism would not disappear, tying individuals to a 
continuous consumption cycle, which many critics (e.g. Klein, 2000) have shown to have a range of negative effects on people, societies and the environment.

What is important for us is to realize that - in the words of Guy Debord - 'it is not just that the relationship to commodities is now plain to see-commodities are now all that there is to see, the world we see is the world of the commodity' (1994: 29). That is, humankind is enmeshed in commodity relations. A study of NikeTown in Chicago, for example, argues that a visit to this consumer haven gives one the sense of a 'festive nature of the processions through the site, with customers cast in the role of explorers and tourists in search of clothing, souvenirs and meanings' (Peñaloza, 1998: 379). Our perceptual apparatus cannot 'not see' the commodity; it is everywhere. The commodity is being produced and reproduced at a variety of different levels of reality and representation, resulting in what Debord calls a 'spectacle': 'The Spectacle is not a collection of images; rather it is a social relationship between people that is mediated by images' (Debord, 1994: 12). These images - in the form of news, advertising and entertainment - are continuously produced and reproduced by the media and culture industries (Adorno and Horkheimer, 1979), resulting in what Lacanians would call 'Homo Symbolicus', which implies a shift from a naturalist to a culturalist conception of need and desire (Stavrakakis, 2006: 89).

The important Lacanian contribution to this debate is that the 'enjoyment economy' (Baudrillard, 2001; Gilmore et al., 1998) is not only a post-World War II or 'postmodern' invention. Instead, enjoyment must be seen at the heart not only of capitalist organization but also of how human subjectivity and hence society as such function. What is important to realize here is that, for Lacan, desire is located in the realm of the symbolic Other, the relational structure of language that makes up society. As the fetishist deals with his or her anxiety (lack) by accepting the Law of the Nameof-the-Father, the Other becomes, what Deleuze and Guattari (1988) call a 'desiring machine' that constitutes the subject. With Lacan — as with Deleuze and Guattari-this fetishization process exits the realm of the Freudian clinic to enter the wider scene of social relations. Lacan's formula to describe what Deleuze and Guattari (1988) later call the 'desiring machine' is $\$ \diamond a$, where ' $\$$ ' is the 'barred' or 'divided' subject (as the subject, according to Lacan, can never have a full identity) and the small ' $a$ ' is the object of desire that is, nevertheless, always unattainable. The Nike brand, for example, promises all sorts of amazing experiences and enjoyments when one buys a pair of one of their latest trainers. Yet, once bought, we realize that we cannot jump quite as high as 'Air Jordan' or play golf as skillfully as Tiger Woods. The symbolic regime of the Other is thus always lacking, which, however, does not prevent us from desiring and believing in it. This is what Lacan (2007: 108) calls fantasy. It is this fantasy that is at the heart of Lacan and Granoff's (1956) conception of 'fetishism', which they describe as a process of the subject transferring his or her anxiety to a symbolic system, or what Lacan calls the Name-of-the-Father. What contemporary consumer capitalism has arguably achieved is that it has provided a symbolic system onto which the subject's constitutive anxieties (lack) can be transferred, creating a set of fantasies for people to believe in. Nike and its global brand appeal is at the heart of this relationship.

However, as we have already discussed, this Other, this symbolic system, can never be fully functioning. According to Lacan, there will always be a lack at the heart of the Other, which he calls jouissance, operating in the realm of the Real, which cannot be symbolized. In other words, Nike's brand is always vulnerable, as we have seen with the anti-Nike resistance campaign that started in the 1990s. There is thus a radical openness in the Other, which introduces contingency and possibility of change right at the heart of the symbolic order. On the one hand, this change is the very stuff (object $a$ ) that keeps Nike's marketing machinery going, introducing ever more fantasies for the consuming subject (\$) to believe in. That is, because of this lack Nike has the opportunity to create ever new products (object $a$, corporate innovation) for consumers to desire, leading 
to new accumulation potentials. On the other hand, it is precisely this lack that points to the Lacanian realization that every fantasy has to break down at some point. Jouissance, or failure, is at the very heart of the structure of a marketing fantasy.

However, according to Lacan, there is something else that describes the jouissance of capitalism. For him, capitalism is all about the capture of jouissance-or any surplus jouissance that is available - to make it work for itself. 'Something changed', he says, 'in the master's discourse at a certain point in history' when 'surplus jouissance became calculable, could be counted, totalized. This is where what is called the accumulation of capital begins' (Lacan, 2007: 177). That is, for Lacan, capitalism starts with the attempt to calculate, account for and value surplus jouissance, or enjoyment, that has hitherto been simply unaccounted waste (Zupančič, 2006: 170). For Lacan, Marx's concept of 'surplus value' - which is the goal of all capitalist organizing - is therefore an expression of capital's attempt to capture the worker's surplus jouissance:

What Marx denounces in surplus value is the spoliation of jouissance. And yet, this surplus value is a memorial to surplus jouissance, its equivalent to surplus jouissance. 'Consumer society' derives its meaning from the fact that what makes it the 'element', in inverted commas, described as human is made the homogeneous equivalent of whatever surplus jouissance is produced by our industry - an imitation surplus jouissance, in a word. (Lacan, 2007: 80-81)

In effect, what Lacan does to Marx here is what he has already done to Freud. He generalizes Marx's analysis of surplus value production, lifting it from the purely economic sphere of commodity production to that of language and the production of subjectivity as such (see also MacCannell, 2006). So, within a capitalist system jouissance becomes the organizing principle of firms, such as Nike, that are dependent on consumers enjoying themselves. This enjoyment has to be re-created on a constant basis. To do this, Lacan says, capital imitates surplus jouissance. Now enjoyment becomes a political and economic factor, 'be it in the form of promise ('make another effort, work a little harder, show a little more patience, and you will finally get it!'), or in the form of the imperative 'Enjoy!' which often weighs down our contemporary existence in a rather suffocating manner' (Zupančič, 2006: 156). The example Zupančič (2006: 171) uses is that of adverts promising us that anything is possible. Nike's slogan 'Just Do It', too, can be seen as a call to make the impossible possible, promising endless enjoyment. As Fleming (2009) argues, contemporary workplaces often operate quite explicitly under the imperative 'Enjoy', as 'fun culture' becomes a tool for a new kind of management of enjoyment.

Lacan's analytical critique is, thus, that Marx did not recognize surplus value as surplus jouissance. For Lacan (2007: 80-81), Marx sees capital and the world of work as the destruction, or spoliation, of jouissance. According to Lacan, the opposite is true. Capital has precisely succeeded in the spectacular fashion it has because it has captured enjoyment in two ways: First, it has been able to create a 'desiring machine' (Deleuze and Guattari, 1988) that lets people dream and live a life of fantasy, which is precisely what gets us out of bed in the morning, go to work, go shopping, etc. Second, it has imitated surplus jouissance to create an ever new imperative for enjoyment. The problem Zupančič (2006: 172-173) sees with this kind of consumer enjoyment is that it excludes, what Freud calls, the 'death drive'; the possibility of paying the ultimate price, the will to take the highest risk to enter a new life. So, pretty quickly Nike's consumers realize that the fantasy they have been promised does not provide full enjoyment. Lack is introduced, which Nike, of course, will try to fill again with a new product. If one of these lacks is related to consumers' concerns regarding the corporate social responsibility of the corporation, including its treatment of foreign workers and its ecological footprint, then Nike's hope is that its new 
brand 'nikeresponsibility.com' will provide a new fantasy fix. The role of management is precisely to keep up with the demands of new fantasies that consumers, but also organizational members can buy into. However, given that we are often simply dealing with the imitation of enjoyment, the danger for the company is that one day consumers will simply flock to a new fantasy they can believe in.

\section{Conclusions}

While reading some contemporary Marxian critics (e.g. Callinicos, 2003) arguing for the virtues of the planned, socialist economy, one is reminded of the following words by Lacan: 'It's not because one nationalizes the means of production at the level of socialism in one country that one has thereby done away with surplus value, if one doesn't know what it is' (2007: 108). Hence, it is not enough to accuse capitalism of artificially creating pseudo-needs and pseudodesires. Marx, like his analysis of commodity fetishism, can sometimes be read in such a fashion: capital destroys original jouissance and our natural way of relating to the Other. Lacan does away with this language of the humanist and authentic ego. For him, commodity relations do not produce false needs or desires, 'false consciousness' or false consumption patterns. The Lacanian point is to show that all social relations are, in effect, 'false' as they are constituted by a lack that is at the heart of the subject, as well as the Other. What we call 'capitalism' is the regime that has managed to fill this lack with a set of social relations that are geared towards commodity fetishism and economic surplus value, as Marx has shown in detail. The Lacanian addition to this analysis is the point that these economic relations are related to a set of much wider linguistic relations at the heart of which is the question of how to produce enjoyment or, what Lacan calls, jouissance.

According to Lacan, there is jouissance because both the subject and the Other can never fully attain an identity. There is always a constitutive lack at the heart of both the subject and the symbolic order, which Lacan calls the Other. If the symbolic order, or what Lacan calls the 'master', wants to stay in power, then this requires a continuous filling of this lack or gap. This is precisely the task of the (commodity) fetish, providing an image or linguistic system that enables the individual to identify with, and enjoy, the Other. This implies that, for Lacan (1998: 203ff), the question of the subject is always already one of alienation. It is this economy of the alienation of the consumer that is at the heart of the language of the media, advertising and today's political economy. The thousands of advertising messages that hit each individual on a daily basis come with the promise of fulfilling culturally acquired needs dominated by commodity relations.

In addition, Lacan argues in Seminar XVII that capital has managed to imitate some aspects of jouissance, in order to put it to work for the production and consumption of commodities. This imitation often involves an imperative 'Enjoy!', which is a mute, socially sanctioned enjoyment that is bereft of, what Freud calls, the death drive. Yet, according to Lacan, it is the death drive that provides real jouissance, which cannot be imitated. 'One could say that for the Lacan of Seminar $X V I I$ jouissance is nothing but the inadequacy of the signifier to itself, that is to say, its inability to function 'purely', without producing a useless surplus' (Zupančič, 2006: 159). That is, brands, such as Nike, are nothing without imitating jouissance. They need to borrow value from outside themselves for their own existence. When one reads Nike's advertising slogans, like 'Heroes are people who believe they can do it' or 'On the field there are no winners; only survivors,' one gets perhaps a short glimpse of this outside, of death, but only in a 'dumped down', easily consumable package. Instead of death, what these slogans seem to be doing is to reactivate the infant's 'mirror stage' of narcissism, the stage where there was faith in the existence of the mother's phallus, that stage 
where there was no fear of castration. For the consumer, the purchase of the trainer gets unconsciously interwoven with being the winner, the survivor, the hero; thus deriving meaning and comfort from Nike's slogans. Freud (2003/1916) points out that libidinal energy has the stubborn, unchangeable character of being attracted to these narcissistic points of satiation. It reverts to points of fixation in infancy and escapes to find them in different ways. 'Just do it', the mother says, and the infant is overjoyed when she reaches the goal set out by the mother. However, when the 'mirror stage' comes to an end, the mother is being replaced by the Father and the Name-of-theFather offering compensation for the fear of following into the footsteps of the castrated mother. 'The winner', 'the survivor', 'the hero'- these are all symbolic images provided by the Name-ofthe-Father, which, for Lacan and Granoff (1956), are at the heart of fetishistic behaviour, fulfilling the task of plugging the hole of the subject. This is when the phallus takes over, the Law, the symbolic relations of images and signifiers, the never-ending stream of advertisements, public relations and 'news' stories. This is the world of Nike. Is it a coincidence that the 'swoosh' looks a bit like a phallus? Rippin (2003) does not think it is.

We should note again that the contemporary 'individual consumer' should be seen in a pathological, socio-historical way, as she is produced by a dialectical relationship between the Other and the self. Hence, when we talk about perverse contradictions the individual Nike consumer is exposed to, we need to connect them to real social antagonisms existing in society (Laclau and Mouffe, 1985). It is for this social antagonism that Debord can sound rather universal and defeatist when he says: 'the spectacle is essentially tautological ... it is the sun that never sets on the empire of modern passivity. It covers the entire globe, basking in the perpetual warmth of its own glory' (1994: 15). While Nike and all the other 'super brands' seem indeed all-encompassing, one should never forget the Lacanian point that at the heart of each social relation is a fundamental and constituting lack. Zupančič (2006) reminds us that what is at stake in this process is not simply the success of the brand, but the success of the constitution of the subject and the symbolic order as such. If the symbolic order fails to repeat itself, if it fails to occupy the lack of the subject, then its own constitute lack becomes exposed and the structure collapses into itself. Once the (advertising) repetition machine stops to function, or someone or something puts a spanner into the works, possibilities of radical contingency emerge, the outcome of which are not predictable, precisely because a language for another Other-or what Laclau and Mouffe (1985) call 'hegemony'-is always the outcome of social struggle. Each signifier, however powerful it may seem, is therefore 'empty' (Laclau, 1996: 36ff). This emptiness is a breeding space for resistances, alternatives and differences. This is the space for culture jamming activists, such as those of Adbusters, which is 'a global network of culture jammers and creatives working to change the way information flows, the way corporations wield power, and the way meaning is produced in our society' (adbusters.org).

What this therefore tells us is that there is struggle for meaning, struggle for the symbolic, struggle for the way subjects are produced, not only in contemporary capitalism but in all societies. The Lacanian contribution to the understanding of modern subjectivity is that at the very heart of the subject is struggle. We can name this the struggle over and for jouissance, for enjoyment. What capital has successfully managed to do is to create a 'desiring machine' that continuously re-produces enjoyments. The crucial Lacanian insight is, however, that this enjoyment can never fully 'fix' the subject; there will hence always be a lack that needs to be filled with ever new joyful content. This need to fill this lack again and again is precisely also the event of resistance. It is this lack that needs to be understood as a struggle for jouissance and enjoyment, the outcome of which is never fully predictable. 


\section{Notes}

This is a revised version of an article presented at the Lacan at Work Conference, held at Copenhagen Business School, Copenhagen, Denmark, 4-6 September 2008. Some minor parts of this text are also based on two conference papers presented by Böhm (2001a, 2001b). We would like to thank the organizers and participants of these conferences, and in particular Yannis Stavrakakis, as well as the editors and reviewers of this special issue for the invaluable comments on our article. All shortcomings are, of course, ours alone.

\section{References}

Adorno, Theodor W. (2005) Minima Moralia: Reflections on a Damaged Life, trans. Edmund Jephcott. London: Verso.

Adorno, Theodor W. and Horkheimer, Max (1979) Dialectic of Enlightenment. London: Verso.

Althusser, Louis and Balibar, Étienne (1970) Reading 'Capital', trans. Ben Brewster. London: New Left Books.

Arnaud, Gilles (2002) 'The Organization and the Symbolic: Organizational Dynamics Viewed from a Lacanian Perspective', Human Relations 55(6): 691-716.

Arnaud, Gilles and Vanheule, Stijn (2007) 'The Division of the Subject and the Organization: A Lacanian Approach to Subjectivity at Work', Journal of Organizational Change Management 20(3): 359-69.

Barrett, Michèle (1991) The Politics of Truth: From Marx to Foucault. Stanford, CA: Stanford University Press.

Baudrillard, Jean (2001) Selected Writings, 2nd edn. ed. Mark Poster. Cambridge: Polity Press.

Benjamin, Walter (1999) The Arcades Project, trans. Howard Eiland and Kevin McLaughlin. Cambridge, MA: The Belknap Press of Harvard University Press.

Billig, Michael (1999) 'Commodity Fetishism and Repression: Reflections on Marx, Freud and the Psychology of Consumer Capitalism', Theory and Psychology 9(3): 313-29.

Böhm, Steffen (2001a) 'Walter Benjamin and the Modern Subject's Experience of the Other', paper presented at the 17th EGOS Colloquium, University of Lyon.

Böhm, Steffen (2001b) 'Fetishism in Consulting, or, The Dancing Techno-Knowledge Commodity', paper presented at the Critical Management Studies Conference, University of Manchester.

Böhm, Steffen (2005) 'Fetish Failures: Interrupting the Subject and the Other', in Alison Pullen and Stephen Linstead (eds) Organization and Identity, pp. 127-61. London: Routledge.

Böhm, Steffen (2006a) Repositioning Organization Theory. New York, NY: Palgrave Macmillan.

Böhm, Steffen (2006b) 'The Carousel Event', in P. Case, S. Lilley and T. Owens (eds) The Speed of Organization, pp. 199-224. Copenhagen: Copenhagen Business School Press.

Böhm, Steffen (2007) 'Reading Critical Theory', in C. Jones and R. ten Bos (eds) Philosophy and Organization, pp. 101-15. London: Routledge.

Boje, David M. (2001) 'Carnivalesque Resistance to Global Spectacle: A Critical Postmodern Theory of Public Administration', Administrative Theory and Praxis 23(3): 431-58.

Brewis, Joanna and Linstead, Stephen (2000) Sex, Work and Sex Work: Eroticizing Organization. London: Routledge.

Brosses, Charles de (1760) Du Culte des dieux fétiches. Paris: Fayard, Corpus des Oeuvres de Philosophie.

Buck-Morss, Susan (1989) The Dialectics of Seeing: Walter Benjamin and the Arcades Project. Cambridge, MA: MIT Press.

Bullert, Bette Jean (1999) 'Strategic Public Relations, Sweatshops and the Making of a Global Movement', in The Joan Shorenstein Centre on the Press, Politics and Public Policy: Working Paper Series. Working paper: 2000-14, Harvard College.

Callinicos, Alex (2003) An Anti-Capitalist Manifesto. Cambridge: Polity Press. 
Contu, Alessia (2008) 'Decaf Resistance: On Misbehavior, Cynicism and Desire in Liberal Workplaces', Management Communication Quarterly 21: 364-79.

Danaher, Kevin and Mark, Jason (2003) Insurrection. London: Routledge.

Debord, Guy (1994) The Society of the Spectacle, trans. Donald Nicholson-Smith. Brooklyn, NY: Zone.

Deleuze, Gilles and Guattari, Félix (1988) A Thousand Plateaus, trans. B. Massumi. Minneapolis, MN: University of Minnesota Press.

Domberger, Simon (1998) The Contracting Organization: A Strategic Guide to Outsourcing. Oxford: Oxford University Press.

Driver, Michaela (2009a) 'From Loss to Lack: Stories of Organizational Change as Encounters with Failed Fantasies of Self, Work and Organization', Organization 16(3): 353-69.

Driver, Michaela (2009b) 'Struggling with Lack: A Lacanian Perspective on Organizational Identity', Organization Studies 30: 55-70.

Driver, Michaela (2009c) 'Encountering the Arugula Leaf: The Failure of the Imaginary and its Implications for research on Identity in Organizations', Organization 16(4): 487-504.

Essers, Juup, Böhm, Steffen and Contu, Alessia (2009) 'Corporate Robespierres, Ideologies of Management and Change', Journal of Organizational Change Management 22(2): 129-40.

Fleming, Peter (2009) Authenticity and the Cultural Politics of Work. Oxford: Oxford University Press.

Foo, Lora Jo and Fortunato Bas, Nikki (2003) Free Trade's Looming Threat to the World's Garment Workers.

Sweatshop Watch Working Paper. Available from: www.sweatshopwatch.org

Freud, Sigmund (1924) 'Neurosis and Psychosis', in The Standard Edition of the Complete Psychological Works of Sigmund Freud, Volume XIX (1923-1925): The Ego and the Id and Other Works, pp. 147-54. London: Norton.

Freud, Sigmund (1927) 'Fetishism,' in The Pelican Freud Library, Vol 7, On Sexuality: Five Essays on the Theory of Sexuality and other Works. London: Penguin.

Freud, Sigmund (2003/1916) 'Resistance and Repression', in Introductory Lectures on Psychoanalysis, pp. 330-48. New Delhi: Shrijee's Book International.

Fromm, Erich (1969) The Sane Society. London: Rinehart.

Gamman, Lorraine and Makinen, Merja (2004) Female Fetishism: A New Look. London: Lawrence and Wishart.

Gereffi, Gary and Korzeniewicz, Miguel (1994) Commodity Chains and Global Capitalism. Westport, CT: Praeger.

Gilmore, James et al. (1998) 'Welcome to the Experience Economy', Harvard Business Review, July/August: $97-105$.

Grosz, Elizabeth (1990) Jacques Lacan: A Feminist Introduction. London: Routledge.

Harding, Nancy (2007) 'On Lacan and the Becoming-ness or Organization/Selves', Organization Studies 28(11): 1761-73.

Jones, Campbell and Spicer, André (2005) 'The Sublime Object of Entrepreneurship', Organization 12(2): 223-46.

Klein, Naomi (2000) No Logo, No Space, No Choice, No Jobs: Taking Aim at the Brand Bullies. London: Flamingo.

Knight, Graham and Greenberg, Josh (2002) 'Promotionalism and Subpolitics: Nike and Its Labor Critics', Management Communication Quarterly 15(4): 541-70.

Knights, David and Willmott, Hugh (1989) 'Power and Subjectivity at Work: From Degradation to Subjugation in Social Relations', Sociology 23(4): 535-58.

Lacan, Jacques (1977) Écrits: A Selection, trans. Alan Sheridan. London: Tavistock.

Lacan, Jacques (1998) The Four Fundamental Concepts of Psychoanalysis, trans. Alan Sheridan, ed. JacquesAlain Miller. London: Vintage.

Lacan, Jacques (2006) Le séminaire, Livre XVI: D'un Autre à l'autre, ed. Jacques-Alain Miller. Paris: Seuil. Lacan, Jacques (2007) The Seminar of Jacques Lacan, Book XVII: Other Side of Psychoanalysis, ed. JacquesAlain Miller, trans. Russell Grigg. New York, NY: Norton. 
Lacan, Jacques and Granoff, Wladimir (1956) 'Fetishism: The Symbolic, the Imaginary and the Real', in

S. Lorand and M. Balint (eds) Perversions: Psychodynamics and Therapy. New York, NY: Random House.

Laclau, Ernesto (1996) Emancipation(s). London: Verso.

Laclau, Ernesto and Mouffe, Chantal (1985) Hegemony and Socialist Strategy. London: Verso.

Louie, Miriam Ching Yoon (2001) Sweatshops Warriors: Immigrant Women Workers Take on the Global Factory. Cambridge, MA: South End Press.

Lyotard, Jean-François (2004) Libidinal Economy. London: Continuum.

MacCannell, Juliet Flower (2006) 'More Thoughts for the Times on War and Death: The Discourse of Capitalism in Seminar XVII', in Justin Clemens and Russel Grigg (eds) Jacques Lacan and the Other Side of Psychoanalysis: Reflections on Seminar XVII, pp. 195-215. Durham, NC: Duke University Press.

Marcuse, Herbert (1987) Eros and Civilization: A Philosophical Inquiry Into Freud. London: Routledge.

Marsden, Richard (1999) The Nature of Capital: Marx after Foucault. London: Routledge.

Marx, Karl (1964) The Economic and Political Manuscripts of 1844. Available from: darkwing.uoregon.edu

Marx, Karl (1976) Capital: A Critique of Political Economy, Vol. 1, trans. Ben Fowkes. London: Penguin.

Miklitsch, Robert (1998) From Hegel to Madonna: Towards a General Economy of 'Commodity Fetishism'. Albany, NY: SUNY Press.

Peñaloza, Lisa (1998) 'Just Doing It: A Visual Ethnographic Study Of Spectacular Consumption Behaviour at

Nike Town', Consumption, Markets and Culture 2(4): 337-465.

Pietz, William (1985) 'The Problem of the Fetish, I.', Res 9: 5-17.

Pietz, William (1987) 'The Problem of the Fetish II: The Origin of the Fetish', Res 13: 23-45.

Pietz, William (1988) 'The Problem of the Fetish IIIa: Bosman's Guinea and the Enlightenment Theory of Fetishism', Res 16: 105-123.

Pietz, William (1993) 'Fetishism and Materialism: The Limits of Theory in Marx', in Emily Apter and William Pietz (eds) Fetishism as Cultural Discourse. Ithaca, NY: Cornell University Press.

Polhemus, Ted and Randall, Housk (1994) Rituals of Love: Sexual Experiments, Erotic Possibilities. London: Picador.

Rippin, Ann (2003) 'Images of Athena and Hera in Nike's “Goddess" Campaign', ephemera: theory and politics in organization 3(3): 185-96.

Robbins, Bruce (2002) 'The Sweatshop Sublime', PMLA 117 (1): 84-97.

Rodríguez-Garavito, César A. (2005) 'Global Governance and Labor Rights: Codes of Conduct and AntiSweatshop Struggles in Global Apparel Factories in Mexico and Guatemala', Politics and Society 33: 203-33.

Roberts, John (2005) 'The Power of The Imaginary in Disciplinary Processes', Organization 12(5): 619-42. Saussure, Ferdinand de (1995) Course in General Linguistics, trans. R. Harris. London: Gerald Duckworth. Sheridan, Alan (1977) 'Translator's Note', in Jacques Lacan, Écrits: A Selection. London: Tavistock.

Soldatenko, María A. Gutierrez de (1999) 'Made in the USA: Latinas/os? Garment Work and Ethnic Conflict in Los Angles' Sweat Shops', Cultural Studies 13(2): 319-34.

Spencer, Deborah and Praparpun, Yada (2002) 'The Anti-Sweatshop Movement in the US: Liberation of the Masses or Another Form of Cultural Imperialism?', in Seth Nii Asumah and Ibipo Johnston-Anumonwo (eds) Diversity, Multiculturalism, and Social Justice, pp. 333-60. Binghamton, NY: Global Academic Publishing.

Spicer, André and Böhm, Steffen (2007) 'Moving Management: Theorizing Struggles against the Hegemony of Management', Organization Studies 28: 1667-98.

Stavrakakis, Yannis (2000) 'On the Critiqure of Advertising Discourse', Third Text 14(51): 85-90.

Stavrakakis, Yannis (2006) 'Objects of Consumption, Causes of Desire: Consumerism and Advertising in Societies of Commanded Enjoyment', Gramma 14: 83-106.

Stavrakakis, Yannis (2007) The Lacanian Left: Psychoanalysis, Theory, Politics. Edinburgh: Edinburgh University Press. 
Stratton, Jon (2000) The Desirable Body: Cultural Fetishism and the Erotics of Consumption. Champaign,

IL: University of Illinois Press.

Taussig, Michael (1980) The Devil and Commodity Fetishism in South America. Chapel Hill, NC: University of North Carolina Press.

Thompson, Paul (1983) The Nature of Work. Basingstoke: Macmillan.

Vanheule, Stijn et al. (2003) 'Burnout and Intersubjectivity: A Psychoanalytic Study from A Lacanian Perspective', Human Relations 56(3): 321-38.

War on Want (2005) Asda Wal-Mart: The Alternative Report. Available from: www.waronwant.org

War on Want (2006) 'Fashion Victims' The True Cost of Cheap Clothes at Primark, Asda and Tesco. Available from: http://www.waronwant.org/download.php?id=496

Žižek, Slavoj (1989) The Sublime Object of Ideology. London: Verso.

Žižek, Slavoj (1997) The Plaque of Fantasies. London: Verso.

Žižek, Slavoj (2006) The Parallax View. Cambridge, MA: MIT Press.

Zupančič, Alenka (2006) 'When Surplus Enjoyment Meets Surplus Value', in Justin Clemens and Russel Grigg (eds) Jacques Lacan and the Other Side of Psychoanalysis: Reflections on Seminar XVII, pp. 15578. Durham, NC: Duke University Press.

\section{Biographies}

Steffen Böhm is Reader in Management at the University of Essex. He holds a PhD from the University of Warwick. His research focuses on critiques of the political economy of organization and management. He was a co-founder of the open-access journal ephemera: theory and politics in organization (www.ephemeraweb.org), and is co-founder and co-editor of the new open-access publishing press MayFlyBooks (www.mayflybooks.org) as well as Interface: A Journal for and about Social Movements (www.interfacejournal.net). He has published three books: Repositioning Organization Theory (Palgrave), Against Automobility (Blackwell) and Upsetting the Offset: The Political Economy of Carbon Markets (Mayfly). Address: Essex Business School, University of Essex, Wivenhoe Park, Colchester, CO4 3SQ, UK. [email: steffen@essex.ac.uk]

Aanka Batta is a PhD student at Essex Business School, University of Essex, pursuing her studies in Critical Management. Her research topic is Commodity Fetishism as seen through a psychoanalytic lens, for which her training comes from the Centre for Psychoanalytic Studies at the University of Essex. She holds a BSc in Economics and Management and an MA in Psychoanalysis and Management. Her current research interests are in group psychodynamics, critical management studies, consumerism and motivation theory. Address: Essex Business School, University of Essex, Wivenhoe Park, Colchester, CO4 3SQ, UK. [email: abatta@essex.ac.uk] 